\title{
Antibacterial Activity of Rhamnus prinoides extracts against Staphylococcus aureus and Escherichia coli
}

kindu geta ( $\sigma$ kindu2012@gmail.com )

Debre Tabor University

Mulugeta Kibret

Bahir Dar University

Research article

Keywords: Antibacterial activity, Escherichia coli, MBC, MIC, Rhamnus prinoides, Staphylococcus aureus.

Posted Date: December 17th, 2019

DOI: https://doi.org/10.21203/rs.2.17220/v3

License: (9) This work is licensed under a Creative Commons Attribution 4.0 International License.

Read Full License 


\section{Abstract}

Medicinal plants offer a major and accessible source of health care to people living in developing countries. Increasing in resistant microbial infections intensified the search for new, safer, and more efficacious agents to combat serious microbial infections. Acanthus sennii is one of the medicinal plants used traditionally for treatment of different infectious diseases in Ethiopian. Therefore, this research was carried out to evaluate antibacterial activity of Acanthus sennii against pathogenic bacteria. The antimicrobial activity tests of the plant extracts against pathogenic bacteria were carried out by the agar well diffusion method. Broth dilution and streak plate method were used to determine MIC and MBC of extracts respectively. The results revealed that ethanol extracts of leaves showed the highest antibacterial activity against standard strains of S.aureus with inhibition zone of $14 \pm 0.58 \mathrm{~mm}$ and $17 \pm 0.67 \mathrm{~mm}$ at $50 \mathrm{mg} / \mathrm{ml}$ and at $25 \mathrm{mg} / \mathrm{ml}$ respectively. Ethanol extracts of buds showed the highest antibacterial activity against standard strains of S.aureus with inhibition zone of $25.67 \pm 0.67 \mathrm{~mm}$ at $100 \mathrm{mg} / \mathrm{ml}$. The lowest mean MIC value $(2.6 \pm 0.52 \mathrm{mg} / \mathrm{ml})$ was recorded with ethanol extract of leaves against standard strains and clinical isolates of $\mathrm{S}$. aureus. The lowest mean $\mathrm{MBC}$ value $(4.2 \pm 1.04 \mathrm{mg} / \mathrm{ml})$ was recorded with ethanol extract of leaves against standard strains of S. aureu. Acanthus sennii could be a good candidate in the search for new antibacterial agents from natural products against bacterial pathogens. Therefore, further studies are needed to study their toxicology and isolate the bio- active components from this plant. Key words: Acanthus sennii, Antibacterial activity, MIC, MBC, pathogenic bacteria

\section{Background}

Currently, drug resistance to human pathogenic bacteria has been commonly reported from all over the world. Staphylococcus aureus and Escherichia coli were observed to be the most frequent pathogenic bacteria. Worldwide, $50 \%$ of medicines are inappropriately prescribed while $50 \%$ of the medicines are inappropriately used [40]. Prolonged use of antimicrobial agents led to microbial adaptation, resulting in the development of resistance in microorganisms and the consequent failure of antibiotic therapy, has led to hundreds of thousands of deaths annually [34]. These developments and increasingly resistant microbial infections intensified the search for new, safer, and more efficacious agents to combat serious microbial infections [43].

Plants have been used as medicinal bases since ancient times and even today plant-based pharmacopoeias continue to play an essential role in world health care [44]. In recent times focus on plant research have increased all over the world and there is widespread of belief that the green medicines are healthier and harmless than the synthetic ones [28]. Plants are good sources for new, safe, biodegradable and renewable drugs. However, the use of plants as therapeutic agents in addition to being used as food is age- long [19]. Medicinal plants are recognized for their capacity to produce a wealth of bioactive compounds and mankind has used many species for centuries to treat a variety of diseases [49]. Herbal medicines are prepared from a variety of plant materials-leaves, stems, roots, barks, fruits, seeds, flowers, and so on. They usually contain most of the biologically active ingredients and are used primarily for treating mild to chronic ailments. 
Plants have played a central part in combating many diseases in human and domestic animals in many local communities, including Africa [10]. Numerous plants containing volatile oils, polyphenols, and alkaloids as active constituents are utilized as popular folk medicines, whereas others gained popularity in the form of phytomedicines [5].

In Ethiopia, medicinal plants have been used from time immemorial to treat different human and livestock ailments [45]. People have been using both plants and animals' species for medication of different animal and human diseases over centuries when there was no modern health service. The practice has been not stopped with the introduction of the modern pharmacotherapy and plant remedies are still the most important and sometimes the only sources of therapeutics for nearly more than $90 \%$ livestock population $[41,17]$.

The familiarity of medicinal plants of Ethiopia and their uses provides vital roles to human and domestic animals health care needs throughout the country [7]. The majority of Ethiopian people especially in rural communities still depend on traditional medicinal plants to treat several diseases because their derived products can be exploited with sustainable, comparative, and competitive advantage including reduced cost, less dangerous, more effective, and readily available [27].

Rhamnus prinoides L'Herit (Rhamnaceae) is one of the Ethiopian medicinal plant that has been used traditionally for the treatment of different infectious diseases. It has different ethno medicinal uses in different countries in Africa. In Kenya, traditionally, different parts of plant are used in the management of Ear, Nose and Throat infections, gonorrhea, malaria and brucellosis [32, 30]. In Ethiopia, leaves, fruits or roots of Rhamnus prinoides are used to treat tonsillitis [9, 24,15, 16, 21]. In addition, different parts of the plant have been used in the management of scabies, hepatitis, tinea capitis, 'chiffea' (Eczema), ringworm and dandruff $[42,25,16,13]$. Moreover, the leaf of the plant is used for the management of waterborne and related diseases [38].

However, Rhamnus prinoides has such advantages; the use of locally made medicines prepared as infusions in hot water or mixed with food to treat infection and the majority of the evidence on the antimicrobial activity of this plant was anecdotal and lacked scientific validity. Moreover, the alarming side effects of synthetic drugs and increasing the resistance of microorganisms towards the present-day drug leads to failure in the treatment of infectious diseases demand a new antimicrobial drug with selective action against new targets in the microbial cells, without irreversible side effects in the host [43]. Even though, the antibacterial activity of the crude extract of Rhamnus prinoides leaves had been studied by previous works in Ethiopia and USA $[8,6,26,50]$; the extract was also evaluated in this study to assure its antibacterial activity as there were differences in geographical areas of plant collection, bacterial stains, solvent system, method of test and the parts of the plant used for extraction purpose. Moreover, there was no study related to the antimicrobial activity of Rhamnus prinoides fruits have been published previously. Therefore, this study was aimed to evaluate the antimicrobial activity of Rhamnus prinoides extracts against pathogenic bacteria. 


\section{Results}

\subsection{Antibacterial activity of Rhamnus prinoides extracts}

The antibacterial activity of water, ethanol, and chloroform extracts of Rhamnus prinoides were tested against standard strains and clinical isolates of $S$. aureus and $E$. coli by agar well-diffusion method. The results showed that plant extracts were active against all the test bacteria to variable extent in a concentration dependent manner. Ethanol extracts of fruits showed the highest antibacterial activity against standard strains of $S$. aureus with mean inhibition zone of $26 \pm 0.58,28.33 \pm 1.2$ and $33.33 \pm 0.9$ $\mathrm{mm}$ at 25,50 and $100 \mathrm{mg} / \mathrm{ml}$ respectively. The lowest antibacterial activity was seen in ethanol, chloroform, and water extracts of leaves against clinical isolates of $E$. coli with an inhibition zone of $11 \pm 0.58,9.67 \pm 0.33$ and $13.67 \pm 0.67 \mathrm{~mm}$ at 25,50 and $100 \mathrm{mg} / \mathrm{ml}$ respectively. However, the water extract of Rhamnus prinoides leaves were devoid of an antibacterial activity against any of the test bacteria and chloroform extracts of leaves were devoid of an antibacterial activity against standard strains and clinical isolates of $E$. coli at $25 \mathrm{mg} / \mathrm{ml}$. Negative control exhibited no zone of inhibition as expected whereas, positive control (disc containing antibiotics) exhibited zones of inhibition against all strains studied (Table 1). The mean zone of inhibition among bacteria showed statistically significant difference at all extracts of fruits and leaves of the plant except water extracts of leaves $(P<0.05)$ at $25 \mathrm{mg} / \mathrm{ml}$.

The statistical analysis of the data showed that there were significant differences among positive control, water, ethanol and chloroform extracts of Rhamnus prinoides fruits and leaves on mean zone of inhibition within each tested bacterium at all concentrations.

Table 1: Antibacterial activity of Rhamnus prinoides extracts against pathogenic bacteria using Agar well diffusion method. 


\begin{tabular}{|c|c|c|c|c|c|}
\hline \multirow[t]{4}{*}{ Plant species } & \multirow{4}{*}{$\begin{array}{l}\text { Plant } \\
\text { Part }\end{array}$} & \multicolumn{4}{|c|}{ Mean Zone of inhibition $(\mathrm{mm})$ at $25 \mathrm{mg} / \mathrm{ml}$} \\
\hline & & \multicolumn{4}{|c|}{ Test bacteria } \\
\hline & & \multicolumn{2}{|c|}{ Staphylococcus aureus } & \multicolumn{2}{|c|}{ Escherichia coli } \\
\hline & & Standard & Clinical & Standard & Clinical \\
\hline \multirow[t]{2}{*}{ Water } & Leaves & $0.00 \pm 0.00^{\mathrm{a} 1}$ & $0.00 \pm 0.00^{\mathrm{a} 1}$ & $0.00 \pm 0.00^{\mathrm{a} 1}$ & $0.00 \pm 0.00^{\mathrm{a} 1}$ \\
\hline & Fruits & $13.67 \pm 0.33^{\mathrm{b} 3}$ & $12 \pm 00^{\mathrm{ab} 3}$ & $12.33 \pm 0.33^{\mathrm{a} 2}$ & $11.33 \pm 0.67^{\mathrm{a} 2}$ \\
\hline \multirow[t]{2}{*}{ Ethanol } & Leaves & $13.67 \pm 0.67^{\mathrm{bc} 3}$ & $12 \pm 0.58^{\mathrm{ab} 3}$ & $14.33 \pm 0.33^{\mathrm{c} 3}$ & $11 \pm 0.58^{\mathrm{a} 2}$ \\
\hline & Fruits & $26 \pm 0.58^{\mathrm{d} 6}$ & $20.67 \pm 0.33^{\mathrm{c} 5}$ & $17.33 \pm 0.33^{\mathrm{b} 4}$ & $14.33 \pm 0.67^{\mathrm{a} 3}$ \\
\hline \multirow[t]{2}{*}{ Chloroform } & Leaves & $6.33 \pm 0.33^{\mathrm{b} 2}$ & $5.67 \pm 0.33^{\mathrm{b} 2}$ & $00^{\mathrm{a} 1}$ & $00^{\mathrm{a} 1}$ \\
\hline & Fruits & $19.33 \pm 0.9^{\mathrm{b} 4}$ & $15.33 \pm 0.33^{\mathrm{a} 4}$ & $18.33 \pm 0.33^{\mathrm{b} 5}$ & $14.67 \pm 0.33^{\mathrm{a} 3}$ \\
\hline $\mathrm{Gm}$ & 0.01 & $21.67 \pm 0.33^{\mathrm{b} 5}$ & $19.67 \pm 0.33^{\mathrm{a} 5}$ & $24.67 \pm 0.33^{\mathrm{c} 6}$ & $22.67 \pm 0.33^{\mathrm{b} 4}$ \\
\hline \multicolumn{6}{|c|}{ Mean Zone of inhibition $(\mathrm{mm})$ at $50 \mathrm{mg} / \mathrm{ml}$} \\
\hline \multirow[t]{2}{*}{ Water 50} & Leaves & $14.67 \pm 0.33^{\mathrm{c} 2}$ & $12.67 \pm 0.33^{\mathrm{ab} 2}$ & $13.67 \pm 0.67^{\mathrm{bc} 2}$ & $11.67 \pm 0.67^{\mathrm{a} 2}$ \\
\hline & Fruits & $21 \pm 0.58^{\mathrm{c} 4}$ & $18.33 \pm 0.33^{\mathrm{b} 4}$ & $18 \pm 1^{\mathrm{b} 3}$ & $15.67 \pm 0.33^{\mathrm{a} 4}$ \\
\hline \multirow[t]{2}{*}{ Ethanol } & Leaves & $18.33 \pm 0.67^{\mathrm{b} 3}$ & $14.67 \pm 0.33^{\mathrm{a} 3}$ & $17.33 \pm 0.33^{\mathrm{b} 3}$ & $14 \pm 0.58^{\mathrm{a} 3}$ \\
\hline & Fruits & $28.33 \pm 1.2^{\mathrm{c} 6}$ & $24.33 \pm 0.67^{\mathrm{b} 6}$ & $22.33 \pm 0.33^{\mathrm{ab} 4}$ & $21.33 \pm 0.33^{\mathrm{a} 6}$ \\
\hline \multirow[t]{2}{*}{ Chloroform } & Leaves & $11.67 \pm 0.33^{\mathrm{c} 1}$ & $10.33 \pm 0.33^{\mathrm{ab} 1}$ & $11.33 \pm 0.33^{\mathrm{bc} 1}$ & $9.67 \pm 0.33^{\mathrm{a} 1}$ \\
\hline & Fruits & $25 \pm 0.58^{\mathrm{c} 5}$ & $20.33 \pm 0.67^{\mathrm{a} 5}$ & $22.33 \pm 0.33^{\mathrm{b} 4}$ & $19 \pm 0.58^{\mathrm{a} 5}$ \\
\hline \multirow[t]{2}{*}{$\mathrm{Gm}$} & 0.01 & $21.67 \pm 0.33^{\mathrm{b} 4}$ & $19.67 \pm 0.33^{\mathrm{a} 45}$ & $24.67 \pm 0.33^{\mathrm{c5}}$ & $22.67 \pm 0.33^{\mathrm{b} 6}$ \\
\hline & \multicolumn{4}{|c|}{ Mean Zone of inhibition(mm) at $100 \mathrm{mg} / \mathrm{ml}$} & \\
\hline \multirow[t]{2}{*}{ Water 100} & Leaves & $18.33 \pm 0.67^{\mathrm{c} 1}$ & $14.67 \pm 0.33^{\mathrm{ab} 1}$ & $16.33 \pm 0.33^{\mathrm{b} 2}$ & $13.67 \pm 0.67^{\mathrm{a} 2}$ \\
\hline & Fruits & $29.33 \pm 0.67^{\mathrm{d} 3}$ & $26.67 \pm 0.9^{c 4}$ & $22.67 \pm 0.33^{\mathrm{b} 4}$ & $20 \pm 0.58^{\mathrm{a} 3}$ \\
\hline \multirow[t]{2}{*}{ Ethanol } & Leaves & $22.33 \pm 0.67^{\mathrm{b} 2}$ & $19.67 \pm 0.33^{\mathrm{a} 2}$ & $20 \pm 0.58^{\mathrm{a} 3}$ & $19.33 \pm 0.9^{a} 3$ \\
\hline & Fruits & $33.33 \pm 0.9^{\mathrm{c} 4}$ & $29.33 \pm 0.33^{\mathrm{b} 5}$ & $27.67 \pm 0.33^{\mathrm{ab} 6}$ & $26.67 \pm 0.33^{a 5}$ \\
\hline \multirow[t]{2}{*}{ Chloroform } & Leaves & $17.33 \pm 0.9^{\mathrm{b} 1}$ & $16 \pm 0.58^{\mathrm{b} 1}$ & $13 \pm 0.58^{\mathrm{a} 1}$ & $11.33 \pm 0.33^{\mathrm{a} 1}$ \\
\hline & Fruits & $30.67 \pm 0.33^{\mathrm{d} 3}$ & $25 \pm 0.58^{\mathrm{c} 3}$ & $27.67 \pm 0.33^{\mathrm{b} 6}$ & $22.33 \pm 0.9^{a 4}$ \\
\hline GM & 0.01 & $21.67 \pm 0.33^{\mathrm{b} 2}$ & $19.67 \pm 0.33^{\mathrm{a} 2}$ & $24.67 \pm 0.33^{\mathrm{c} 5}$ & $22.67 \pm 0.33^{\mathrm{b} 4}$ \\
\hline $\begin{array}{c}\text { Negative } \\
\text { control }\end{array}$ & Water & - & - & - & - \\
\hline
\end{tabular}

Values are expressed as mean of three replicates \pm S.E.M. Values with different letters in the same row and numbers in the same column at each concentration indicate statistically significant differences (Duncan's test, $p<0.05$ ), GM= Gentamicin, - = no bacterial activity. 


\subsection{Minimum inhibitory concentration of Rhamnus prinoides extracts}

Table 2 represented the MIC values of water, ethanol, and chloroform extracts of Rhamnus prinoides fruits and leaves against standard strains and clinical isolates $S$. aureus and E. coli. As shown from the Table, ethanol extract of Rhamnus prinoides fruits showed the lowest MIC value of $1.04 \mathrm{mg} / \mathrm{ml}$ against standard strains of $S$. aureus. Water extract of Rhamnus prinoides leaves showed the highest MIC values $50 \mathrm{mg} / \mathrm{ml}$ against all test bacteria and the chloroform extracts showed the highest MIC values $50 \mathrm{mg} / \mathrm{ml}$ against E. coli.

The MIC values among bacteria showed statistically significant difference at chloroform extracts of leaves $(P<0.05)$. The statistical analysis of the data showed that there were significant differences among water, ethanol and chloroform extracts of Rhamnus prinoides fruits and leaves on MIC within each tested bacterium (Table 2).

Table 2: MIC (mg/ml) of Rhamnus prinoides extracts against pathogenic bacteria using broth dilution.

\begin{tabular}{|c|c|c|c|c|c|c|c|}
\hline \multirow[t]{4}{*}{ Solvent } & \multirow[t]{4}{*}{ Plant Part } & \multicolumn{4}{|c|}{ MIC } & \multicolumn{2}{|c|}{ Control } \\
\hline & & \multicolumn{4}{|c|}{ Test bacteria } & \multirow{3}{*}{ Positive } & \multirow{3}{*}{ Negative } \\
\hline & & \multicolumn{2}{|c|}{ Staphylococcus aureus } & \multicolumn{2}{|c|}{ Escherichia coli } & & \\
\hline & & Standard & Clinical & Standard & Clinical & & \\
\hline \multirow[t]{2}{*}{ Water } & Leaves & $50^{\mathrm{a} 6}$ & $50^{\mathrm{a} 6}$ & $50^{\mathrm{a} 4}$ & $50^{\mathrm{a} 4}$ & + & - \\
\hline & Fruit & $25^{\mathrm{a} 5}$ & $25^{\mathrm{a} 5}$ & $25^{\mathrm{a} 3}$ & $25^{\mathrm{a} 3}$ & + & - \\
\hline \multirow[t]{2}{*}{ Ethanol } & Leaves & $3.13^{\mathrm{a} 3}$ & $3.13^{\mathrm{a} 3}$ & $4.17^{\mathrm{a} 2}$ & $5.21^{\mathrm{a} 2}$ & + & - \\
\hline & Fruit & $1.04^{\mathrm{a} 1}$ & $1.3^{\mathrm{a} 1}$ & $2.08^{\mathrm{a} 1}$ & $2.08^{\mathrm{a} 1}$ & + & - \\
\hline \multirow[t]{2}{*}{ Chloroform } & Leaves & $12.5^{\mathrm{a} 4}$ & $12.5^{\mathrm{a} 4}$ & $50^{\mathrm{b} 4}$ & $50^{\mathrm{b} 4}$ & + & - \\
\hline & Fruit & $2.08^{\mathrm{a} 2}$ & $2.08^{\mathrm{a} 2}$ & $3.13^{\mathrm{a} 12}$ & $3.13^{\mathrm{a} 1}$ & & \\
\hline
\end{tabular}

Values are expressed as mean of three replicates. Values with different letters in the same row and -numbers in the same column at each solvent indicate statistically significant differences (Duncan's test, $p<0.05$ ), $+=$ growth, $-=$ no growth.

\subsection{Minimum bactericidal concentration of Rhamnus prinoides extracts}

As depicted in Table 3, MBC values of water, ethanol and chloroform extracts of Rhamnus prinoides against standard strains and clinical isolates $S$. aureus and $E$. coli. As represented in the Table, ethanol extract of Rhamnus prinoides fruits showed the lowest $\mathrm{MBC}$ value $(2.08 \mathrm{mg} / \mathrm{ml})$ against $S$. aureus. Water 
extract of Rhamnus prinoides leaves showed the highest MIC value of $100 \mathrm{mg} / \mathrm{ml}$ against all test bacteria and the chloroform extracts showed the highest MIC value of $100 \mathrm{mg} / \mathrm{ml}$ against E. coli.

The $M B C$ values among bacteria showed statistically significant difference at ethanol extracts of fruits and chloroform extracts of leaves $(P<0.05)$. The statistical analysis of the data showed that there were significant differences among water, ethanol and chloroform extracts of Rhamnus prinoides fruits and leaves on MBC within each tested bacterium.

Table 3: The MBC (mg/ml) of the Rhamnus prinoides extracts against pathogenic bacteria.

\begin{tabular}{|c|c|c|c|c|c|}
\hline \multirow[t]{4}{*}{ Solvent } & \multirow[t]{4}{*}{ Plant part } & \multicolumn{4}{|c|}{ MBC } \\
\hline & & \multicolumn{4}{|c|}{ Test bacteria } \\
\hline & & \multicolumn{2}{|c|}{ Staphylococcus aureus } & \multicolumn{2}{|c|}{ Escherichia coli } \\
\hline & & Standard & Clinical & Standard & Clinical \\
\hline \multirow[t]{2}{*}{ Water } & Leaves & $100^{4}$ & $100^{5}$ & $100^{4}$ & $100^{3}$ \\
\hline & Fruits & $50^{3}$ & $50^{4}$ & $50^{3}$ & $50^{2}$ \\
\hline \multirow[t]{2}{*}{ Ethanol } & Leaves & $5.21^{\mathrm{a} 1}$ & $5.21^{\mathrm{a} 2}$ & $6.25^{\mathrm{a} 2}$ & $8.33^{\mathrm{a} 1}$ \\
\hline & Fruits & $2.08^{\mathrm{a} 1}$ & $2.08^{\mathrm{a} 1}$ & $4.2^{\mathrm{ab} 1}$ & $5.2^{\mathrm{b} 1}$ \\
\hline \multirow[t]{2}{*}{ Chloroform } & Leaves & $20.83^{\mathrm{a} 2}$ & $25^{\text {a3 }}$ & $100^{\mathrm{b} 4}$ & $100^{\mathrm{b} 3}$ \\
\hline & Fruits & $4.2^{\mathrm{a} 1}$ & $5.2^{\mathrm{a} 2}$ & $6.25^{\mathrm{a} 2}$ & $8.33^{\mathrm{a} 1}$ \\
\hline
\end{tabular}

Values are expressed as mean of three replicates. Values with different letters in the same row and numbers in the same column at each solvent indicate statistically significant differences (Duncan's test, $p<0.05$ ).

\section{Discussion}

Phytochemicals resulting from plant products serve as a trial to develop less toxic and more effective medicines in controlling the growth of microorganism [19].

In the present investigation, water, ethanol and chloroform extracts of Rhamnus prinoides were evaluated for their antimicrobial activity against standard strains and clinical isolates of E. coli and $S$. aureus. The results showed that all water, ethanol and chloroform extracts of the plant were active against tested bacteria in concentration dependent manner.

According to results obtained in the present investigation, water extract of Rhamnus prinoides leaves showed good antibacterial activity against tested bacterial species. On the other hand, Rhamnus prinoides fruits showed the highest antibacterial activity against tested bacterial species. However, the water extract of Rhamnus prinoides leaves was devoid of antibacterial activity against any of the test bacterium at low concentration $(25 \mathrm{mg} / \mathrm{ml})$. 
These results were supported by [33] who reported that, water extracts of Ecbalium elaterium fruit showed antimicrobial activity against all test microorganisms except MRSA, Eminium spiculatum and seed extracts of Lupinus varius exhibited antibacterial activity against all test microorganisms. In a research conducted by [22], an aqueous extract of Sambucus ebulus has effects against $S$. aureus with inhibition zone diameter of $14 \mathrm{~mm}$ at $500 \mathrm{mg} / \mathrm{ml}$ in the agar well diffusion method. Aqueous extracts of fruits of Terminalia bellerica also showed significant activity against all the bacterial and fungal isolates tested with the zone of inhibition ranged from $15-23 \mathrm{~mm}$ [14]. These findings support the current results even if the plants are different.

On the other hand, results of the current study were contrasted with that of [6] and [26] who reported aqueous extract of Rhamnus prinoides leaves was found to be devoid of antibacterial activities against all the test bacterial strains regardless of the concentrations. Another study conducted by [3] reported that, water extracts of Avicennia marina did not give any inhibition against Staphylococcus sp. and Proteus sp. Aqueous extracts of Lippia citriodora, Plantago major, Althaea officinalis, Tilia bengonifolia and Adiantum capillus-veneris showed no significant antibacterial effect [22]. Antibacterial activities of plant extracts in the current study were differing from studies conducted by those authors. The probable reason for this difference may be attributed to concentrations of extracts, types of plants, methods of extraction, methods of the test as well as bacterial strains used.

In ethanol extracts, the highest antibacterial activity was shown in Rhamnus prinoides fruits at all concentrations followed by Rhamnus prinoides leaves at $100 \mathrm{mg} / \mathrm{ml}$ against standard strains of $S$. aureus. The lowest antibacterial activity was seen against clinical isolates of $E$. coli in Rhamnus prinoides leaves at $25 \mathrm{mg} / \mathrm{ml}$. The results of the antibacterial activity of Rhamnus prinoides leaves in this study was in accordance with that of [8] who reported that ethanol and methanol extracts have been shown antimicrobial activity against different species of pathogenic bacteria with clear zone diameter of the wells greater than $10 \mathrm{~mm}$ in all pathogenic bacteria. Results of the current study were also in line with the study of [26] who reported that methanol fraction of Rhamnus prinoides leaves showed the highest antibacterial activity against standard strains of $S$. aureus and the lowest antibacterial activity against clinical isolates of E. coli. According to the study conducted in Algeria, Punica granatum bark ethanol macerate showed to be potent inhibitors against all bacterial strains [20] and methanol water extract of Rhamnus prinoides leaves was active against all bacteria strains [6].

Another study conducted in Jordan showed that ethanol extracts of Mandragora autumnalis fruits exhibited antibacterial activity against all test microorganisms and ethanol extracts of Mandragora autumnalis fruits showed the highest significant antibacterial activity against $E$. coli and MRSA with inhibition zone of $26.0 \pm 1.0 \mathrm{~mm}$ and $28.7 \pm 1.5 \mathrm{~mm}$ respectively [33]. Ethanol extract of Lippia citriodora and Plantago major showed a remarkable antibacterial effect against $S$. aureus with the inhibition zone diameter of $26 \mathrm{~mm}$ and $33 \mathrm{~mm}$ respectively at $500 \mathrm{mg} / \mathrm{ml}$ [22].

On the other hand, ethanol extract of Mimosa pudica twig [4], Lippia citriodora and Plantago major [22] and Ecbalium elaterium [33] were not active against E. coli. Previous study conducted in Bangladesh also 
documented that ethanol extract of Mimosa pudica and Lawsonia inermis twig showed the highest effect against $S$. aureus with zone of inhibition $11.2 \pm 0.14 \mathrm{~mm}$ and $17.1 \pm 0.14 \mathrm{~mm}$ respectively whereas, Lawsonia inermis showed the zone of inhibition $7.20 \mathrm{~mm}$ against $E$. coli in disc diffusion method [4] which were lower than the result of this study. The probable reason for this difference may be attributed to concentrations, type and parts of the plant, methods of the test, methods of extraction as well as bacterial strains used.

In chloroform extract, the highest antibacterial activity was showed in Rhamnus prinoides fruits at 50 $\mathrm{mg} / \mathrm{ml}$ and $100 \mathrm{mg} / \mathrm{ml}$ followed by Rhamnus prinoides at $100 \mathrm{mg} / \mathrm{ml}$ against standard strains of $S$. aureus. The lowest antibacterial activity was seen against clinical isolates of $E$. coli in Rhamnus prinoides leaves at $25 \mathrm{mg} / \mathrm{ml}$. Chloroform extract of Moringa oleifera leaves showed antibacterial activity against $S$. aureus $(11.0 \pm 0.5 \mathrm{~mm})$ at $200 \mathrm{mg} / \mathrm{ml}$ [1] which was lower than the result of the present study and chloroform extracts of Cassia auriculata leaf showed good activity against $S$. aureus $(12 \mathrm{~mm})$ and $E$. coli $(14 \mathrm{~mm})[29]$.

According to the study conducted in India, chloroform extract of Terminalia bellerica fruits showed moderate activity against $E$. coli with zone of inhibition $13.6 \pm 1.5 \mathrm{~mm} \mathrm{[14]}$ and chloroform extract of Lawsonia inermis showed antibacterial activity against S. aureus with zones of inhibition $8.30 \pm 0.14 \mathrm{~mm}$ [4]. Chloroform extract of Trichopus zeylanicus fruits also showed pronounced antibacterial activity at concentration $250 \mathrm{mg} / \mathrm{ml}$ against all tested microorganisms [37].

According to the study conducted in Debre Markos, Ethiopia, the chloroform fraction of Rhamnus prinoides leaves showed that the highest antibacterial activity against standard strains of $S$. aureus at $19.5,39$ and $78 \mathrm{mg} /$ well concentrations with inhibition zone of $11 \pm 0.67,13 \pm 0.58$ and $14.33 \pm 0.33$ respectively and the lowest antibacterial activity was seen against clinical isolates of $E$. coli with no antibacterial activity [26]. However antibacterial activity of current study for S.aureus at all concentration and $E$. coli at 50 and $100 \mathrm{mg} / \mathrm{ml}$ was differing from study conducted by those authors, the antibacterial activity of current study for $E$. coli at $25 \mathrm{mg} / \mathrm{ml}$ was in accordance with study conducted by those authors.

On the other hand, chloroform extract of Lawsonia inermis not active on E. coli and extract of Mimosa pudica twig was devoid of antibacterial activity against $S$. aureus and E. coli in disc diffusion method [4] which was disagreed with this study. The difference may be attributed to plant type and parts, concentrations of extracts, methods of extraction, methods of antibacterial test as well as bacterial strains used.

The results obtained during this investigation elucidated clearly that, Gram-positive bacteria were more sensitive than Gram-negative bacteria towards plant extracts tested. These are likely to be the result of the differences in cell wall structure between Gram-positive and Gram-negative bacteria, with Gramnegative outer membrane acting as a barrier to antibiotics [46]. This result was agreed to that previously recorded by [48] who reported that Gram-negative bacteria were not susceptible to plant extracts when compared to Gram-positive bacteria, and this has been attributed to the external lipopolysaccharide (LPS) 
wall that surrounds the peptidoglycan cell wall of the former. Among the test bacteria, the most susceptible bacterium at all concentration of all plant extracts was standard strains of $S$. aureus and the most resistant was clinical isolates of $E$. coli with different mean zone of inhibition depending on type of plants and concentration of extracts. This data is in close agreement with [2] who report that out of seventy-five extracts; almost all extracts exhibited the highest antibacterial activity against $S$. aureus. On the other hand, ethanol extract of Lawsonia inermis was found to exhibit most effective antibacterial activity against Gram-negative organisms [4]. The mean zone of inhibition among bacteria within the same solvent and concentration for the plant showed statistically significant difference $(P<0.05)$.

All plant extracts have higher zone of inhibition against standard strains than clinical isolates. These differences in the potency of the plants extract against the strains of the same bacterial species might be associated to the susceptibility differences between the strains in which the clinical isolates could have a higher chance of developing a resistance mechanism of reducing the access of the bioactive metabolites to the target sites since they had been isolated from the clinic settings in which resistant strains are common [47].

Among extracts of the plant used in the study, the ethanol extract of Rhamnus prinoides fruits showed the maximum zone of inhibition which was in line with the study of [33] who reported that ethanol extracts of Mandragora autumnalis fruits showed the highest significant antibacterial activity against $E$. coli $(26.0 \pm 1.0 \mathrm{~mm})$ and MRSA $(28.7 \pm 1.5 \mathrm{~mm})$.

The present study showed that, among water extracts of the plant the lowest MIC value $(25 \mathrm{mg} / \mathrm{ml})$ was obtained with Rhamnus prinoides fruits and the highest MIC value $(50 \mathrm{mg} / \mathrm{ml})$ of was obtained with Rhamnus prinoides leaves against all tested bacteria. The MIC value of water extract of Ecbalium elaterium fruits was $64 \mathrm{mg} / \mathrm{ml}$ against $E$. coli [33] which was higher than this study, while aqueous extract of Terminalia bellerica fruit could inhibit the growth of E. coli at minimum concentration of 6.25 $\mathrm{mg} / \mathrm{ml}$ [14] which was lower than this study. The present result was also contrasted with the study of [6] who reported that aqueous extract of Rhamnus prinoides leaves was not active against any of the bacterial strains that were tested.

Regarding ethanol extracts of the plant, the lowest MIC value was found with Rhamnus prinoides fruits $(1.04 \mathrm{mg} / \mathrm{ml})$ against standard strains $S$. aureus. Ethanol extracts of Mandragora autumnalis fruits showed very strong activity against MRSA with the best MIC $(4 \mathrm{mg} / \mathrm{ml})$ and $8 \mathrm{mg} / \mathrm{ml}$ against $E$. coli [33] which were higher than MIC values of Rhamnus prinoides fruits (S. aureus) of the current study whereas the values were in line with Rhamnus prinoides leaves. He also reported that MIC of ethanol extracts of Ecbalium elaterium fruits was $64 \mathrm{mg} / \mathrm{ml}$ against $E$. coli which was higher than this study. Leaf and stem ethanol extracts of Rhamnus prinoides significantly inhibited Staphylococcus aureus, Bacillus subtilis and Streptococcus mutans biofilm formation up to $99.9 \%$ and reduced planktonic cell growth up to $10 \log$ units relative to untreated controls [50]

The current results were disagreed with that of [26] who reported that the MIC value for methanol fraction of Rhamnus prinoides leaves ranged from $32.5 \mathrm{mg} / \mathrm{ml}$ (against E. coli species) to $8.13 \mathrm{mg} / \mathrm{ml}$ (against $S$. 
aureus); and [8] who reported that the MIC of ethanol and methanol gesho extract against standard strains of $E$. coli and $S$. aureus was $97.5 \mathrm{mg} / \mathrm{ml}$, while MIC of 390 was found for clinical isolates of $S$. aureus. MIC of Rhamnus prinoides leaves methanol water extract against $E$. coli and $S$. aureus were 400 $\mathrm{mg} / \mathrm{ml}$ and $200 \mathrm{mg} / \mathrm{ml}$ respectively [6].

In the case of chloroform extract, the lowest MIC value was found with Rhamnus prinoides fruits (2.08 $\mathrm{mg} / \mathrm{ml}$ ) against standard strains and clinical isolates of $S$. aureus and Rhamnus prinoides leaves $(50 \mathrm{mg} / \mathrm{ml})$ against standard strains and clinical isolates of $E$. coli. These results were disagreed with that of [26] who reported that the MIC value for chloroform fraction of gesho against standard strains and clinical isolates of $S$. aureus were $8.13 \mathrm{mg} / \mathrm{ml}$ and $16.25 \mathrm{mg} / \mathrm{ml}$ respectively, while this fraction was found to be devoid of MIC against standard strains and clinical isolates of $E$. coli at the same concentrations. Chloroform extracts of Polygonum aviculare stem and leaf showed MIC value of 18 $\mathrm{mg} / \mathrm{ml}$ and $20 \mathrm{mg} / \mathrm{ml}$ against $S$. aureus and $15 \mathrm{mg} / \mathrm{ml}$ and $18 \mathrm{mg} / \mathrm{ml}$ against E. coli respectively [36]. The probable reason for difference may be attributed to plant type and parts, concentration of bacteria, methods of extraction, methods of the antibacterial test as well as bacterial strains used.

The present study also showed that, the lowest MBC value was found with water extracts of Rhamnus prinoides fruits $(50 \mathrm{mg} / \mathrm{ml})$ and the highest MBC value was found with and Rhamnus prinoides leaves $(100 \mathrm{mg} / \mathrm{ml})$ against all tested bacteria. MBC of water extract of $E$. elaterium fruit was (128) against $E$. coli [33] which was higher than the current study. Ethanol extract of Rhamnus prinoides fruit was showed the lowest MBC $(2.08 \mathrm{mg} / \mathrm{ml})$ against standard strains and clinical isolates of $S$. aureus, [33] reported that ethanol extract of Mandragora autumnalis fruits showed MBC value of $16 \mathrm{mg} / \mathrm{ml}$ and $8 \mathrm{mg} / \mathrm{ml}$ against $E$. coli and MRSA respectively. He also reported that ethanol extracts of Ecbalium elaterium fruits was 64 $\mathrm{mg} / \mathrm{ml}$ against $E$. coli.

MBC value of ethanol extract of Lippia citriodora was 62.5 and 250 against $S$. aureus and E. coli, while MBC value of Plantago major was 31.25 and 125 against $S$. aureus and E. coli [22]. The previous study by [26] showed that the MBC value for methanol fraction of Rhamnus prinoides leaves against $S$. aureus was $16.25 \mathrm{mg} / \mathrm{ml}$ whereas $32.5 \mathrm{mg} / \mathrm{ml}$ and $65 \mathrm{mg} / \mathrm{ml}$ were found against standard and clinical isolates of E. coli respectively. Similar research conducted in Gondar, Ethiopia reported that the MBC gesho extract against standard strains of E. coli and S. aureus was 195 and MBC of $780 \mathrm{mg} / \mathrm{ml}$ was found for clinical isolates of $S$. aureus [8]. These results were higher than the result of the present study.

Regarding chloroform extracts of plants, the lowest MBC value $(4.2 \pm 1.04 \mathrm{mg} / \mathrm{ml})$ was found with Rhamnus prinoides against standard strains of $S$. aureus while the lowest MBC value $(100 \mathrm{mg} / \mathrm{ml})$ was Rhamnus prinoides leaves against standard strains and clinical isolates of $E$. coli. According to [26] the MBC value for chloroform fraction of Rhamnus prinoides leaves was $16.25 \mathrm{mg} / \mathrm{ml}$ against $S$. aureus and devoid of $\mathrm{MBC}$ against standard strains and clinical isolates of $E$. coli at the same concentrations. The probable reason for difference may be attributed to plant type and parts, concentration of bacteria, methods of extraction, methods of antibacterial test as well as bacterial strains used. The results 
obtained during this investigation elucidated clearly that ethanol extract exhibited higher activity followed by chloroform and water extracts showed least activity against all the tested organisms.

\subsection{Conclusion}

The results of the present study clearly indicated that Rhamnus prinoides extracts have potential antibacterial activity against standard and clinical isolates of S.aureus and E. coli in concentration dependent manner. This supports the traditional application of the plant extracts which posse compounds with antimicrobial properties that can be used in novel drugs for the treatment of bacterial diseases. Plant extracts investigated in this study showed higher antibacterial activity on the standard strains than clinical isolates and on gram- positive bacteria than gram- negative bacteria. The results of this study also clearly indicated that the antibacterial activities vary with plant part used, solvent type, concentration of extracts and microorganism tested. Plant extracts have great potential as antimicrobial compounds against S.aureus and E. coli. Thus, they can be used in the treatment of infectious diseases caused by these bacteria.

Based on the findings of the present study, it can be recommended that further studies are needed to study their toxicology, phytochemical analysis and isolate the bio- active components from this valuable plant to innovate new natural antibiotics and minimize the spread of drug resistant bacteria. Since the current study was conducted on antibacterial activity of Rhamnus prinoides extracts against bacterial pathogens, it is recommended that further study be made on antifungal and antiviral activity of this plant against fungal and viral pathogens.

\section{Methods}

\subsection{Study design and area}

Cross- sectional experimental study design was conducted to evaluate the antimicrobial activity of Rhamnus prinoides extracts against some antimicrobial resistant skin pathogens at Bahir Dar University postgraduate Microbiology laboratory, Bahir Dar town from May to June 2018.

\subsection{Plant collection and preparation}

Rhamnus prinoides leaves and fruits were collected from around Bahir Dar town in June 2018. These plant parts were washed with tap water, dried in open air, separately powdered to a suitable size and made ready for extraction [39].

\subsection{Extraction of plant materials}

Plant materials were extracted by maceration technique with chloroform, ethanol, and water solvents with occasional shaking at room temperature for three days. Ground plant materials were soaked with each solvent separately at a 10:1 solvent-to sample ratio $(\mathrm{v} / \mathrm{w})$. The extracts were separately filtered by Whatman No. 1 filter paper and concentrated with a dry oven. Further, fresh solvents were added to the 
residue at the same ratio until required amount of extracts was obtained. The dry extracts were stored in sample bottles at a refrigerator for further use [39].

\subsection{Antimicrobial activities of Rhamnus prinoides extracts}

\subsubsection{Source of the test bacterial pathogens and inoculums preparation}

Bacteria strains (E. coli ATCC 25922 and S.aureus ATCC 25923) and clinical isolates of S. aureus and E. coli were obtained from Amhara regional state central laboratory. The bacteria will be activated by streaking on nutrient agar (Himedia) and incubated at $37^{\circ} \mathrm{C}$ for $24 \mathrm{~h}$. The bacteria used for the study were prepared by inoculating isolates into nutrient broth and incubated at $37^{\circ} \mathrm{C}$ for $24 \mathrm{hrs}$. The culture turbidity was adjusted to a $0.5 \mathrm{McF}$ arland standard (approximately $1 \times 10^{8} \mathrm{CFU} / \mathrm{ml}$ ) using sterile normal saline [12].

\subsubsection{The antimicrobial assays}

The antimicrobial activity tests of the plant extracts against bacteria were carried out by the agar well diffusion method, which is commonly used for screening of the antimicrobial activities of herbal drugs [35]. The standardized bacterial broth cultures prepared in section 2.4.1 were swabbed on Mueller-Hinton agar (Himedia) plates using sterile cotton swabs. After thirty minutes, on each plate, five equidistant wells were made with a $6 \mathrm{~mm}$ diameter sterilized cork borer. The stock solution of each plant extract was prepared using sterilized distilled water at different concentrations $(25,50$ and 100$) \mathrm{mg} / \mathrm{ml}$ and $100 \mu \mathrm{l}$ of each plant extracts were added into the wells aseptically. The plates were allowed to diffuse at room temperature for $2 \mathrm{hrs}$ and incubated at $37^{\circ} \mathrm{C}$ for $18-24 \mathrm{~h}$ in triplicates. Sterile distilled water without plant extract used as negative control and Gentamicin $(0.01 \mathrm{mg} / \mathrm{ml})$ will be used as a positive control respectively. The antimicrobial activity was evaluated by measuring the diameter of the zone of inhibition. The zone of inhibition was measured in $\mathrm{mm}$ using a ruler [31].

\subsubsection{Determination of minimum inhibitory concentration (MIC)}

The two-fold broth dilution method was used to determine the minimum inhibitory concentration (MIC) of extracts, which showed high antimicrobial activity with the agar well diffusion method [12]. The plant extract solutions $(100 \mathrm{mg} / \mathrm{ml})$ were serial dilution with nutrient broth and $20 \mu \mathrm{l}$ of a standard suspension of test organisms were added to each concentration of the extract. Extra test tubes containing peptone water and peptone water plus the test organisms were prepared to serve as a negative and positive control respectively. The broth tubes were incubated at $37^{\circ} \mathrm{C}$ for 24 hours. The MIC value of the extract was taken as the lowest concentration that shows no visible growth or turbidity in the test tube [31].

\subsubsection{Minimum bactericidal concentration (MBC)}

From all tubes showed no visible signs of growth / turbidity (MIC and higher dilutions), loop full of inoculums were streaked on nutrient agar plates and incubated at $37^{\circ} \mathrm{C}$ for 24 hours. The least 
concentration that shows no visible growth after incubation was considered the MBC value of the tested extracts against the tested bacterial species [12].

\subsection{Data analysis}

The statistical differences of the mean zone of inhibition, MIC and MBC of extracts for individual bacterium and among bacteria was carried out by employing one-way analysis of variance followed by Duncan's multiple comparison tests using Statistical Package for the Social Sciences (SPSS) Version 20 software. P-values less than 0.05 were considered statistically significant.

\section{Abbreviations}

\begin{tabular}{ll} 
ATCC: & American type cell collection \\
\hline CLSI: & Clinical and Laboratory Standards Institute \\
\hline E. coli. & Escherichia coli \\
\hline MBC: & Minimum bactericidal concentration \\
\hline MIC: & Minimum inhibitory concentration \\
\hline MRSA: & Methicillin-resistant Staphylococcus aureus \\
\hline NCCLS: & National Committee for Clinical Laboratory Standards \\
\hline S.aureus. & Staphylococcus aureus \\
\hline WHO: & World health organization
\end{tabular}

\section{Declarations}

\section{Ethics approval and consent to participate}

Not applicable

\section{Consent to publish}

Not applicable

\section{Availability of data and materials}

The data is available in the manuscript

\section{Conflicts of Interest}

The author declares no conflicts of interest 


\section{Funding}

No funding source /Not applicable

\section{Author information}

Debre Tabor University, Faculty of Natural and Computational Sciences, Department of Biology

Kindu Geta

\section{Author Contributions}

All works done by the authors

\section{Acknowledgements}

The authors would like to thank Bahir Dar University Department of Biology for supporting media and reagents to conduct this research

\section{References}

1. Abdallah, E. M. Antibacterial properties of leaf extracts of Moringa oleifera Lam. Growing in Sudan. Journal of Advantaces in Medical and Pharmacheutical Sciences, 2015; 5(1): 1-5.

2. Abeysinghe, P. D. Antibacterial activity of some medicinal mangroves against antibiotic resistant pathogenic bacteria. Indian journal of pharmaceutical sciences, 2010; 72(2): 167.

3. Abeysinghe, P. D. and Weeraddana, C. D. S. Screening of petroleum ether, chloroform, ethyl acetate, ethanol and water extracts of medicinal plant, Avicennia marina for antibacterial activity against antibiotic resistant bacteria species, Staphylococcus and. Proteus, 2011; 1-4.

4. Akter, A., Neela, F. A., Khan, M. S. I., Islam, M. S. and Alam, M. F. Screening of ethanol, petroleum ether and chloroform extracts of medicinal plants, Lawsonia inermis and Mimosa pudica L. for antibacterial activity. Indian journal of pharmaceutical sciences, 2010; 72(3): 388.

5. Al-Bakri, A. G. and Afifi, F. U. Evaluation of antimicrobial activity of selected plant extracts by rapid XTT colorimetry and bacterial enumeration. Journal of Microbiological Methods, 2007; 68(1): 19-25.

6. Amabye, T. G. Evaluation of phytochemical, chemical composition, antioxidant and antimicrobial screening parameters of Rhamnus prinoides (Gesho) available in the market of Mekelle, Tigray, Ethiopia. Natural Products Chemistry \& Research; 2015.

7. Belayneh, A., Asfaw, Z., Demissew, S. and Bussa, N. F. Medicinal plants potential and use by pastoral and agro-pastoral communities in Erer Valley of Babile Wereda, Eastern Ethiopia. Journal of Ethnobiology and Ethnomedicine, 2012; 8(1): 42.

8. Berhanu, A. Microbial profile of Tella and the role of gesho (Rhamnus prinoides) as bittering and antimicrobial agent in traditional Tella (Beer) production. International Food Research Journal, 2014; 21(1). 
9. Birhanu, Z. Traditional use of medicinal plants by the ethnic groups of Gondar Zuria District, NorthWestern Ethiopia. Journal of Natural Remedies, 2013; 13(1): 46-53.

10. Bussmann, R. W., Swartzinsky, P., Worede, A. and Evangelista, P. Plant use in Odo-Bulu and Demaro, Bale region, Ethiopia. Journal of ethnobiology and ethnomedicine, 2011; 7(1): 28.

11. Cantón, R., Horcajada, J. P., Oliver, A., Garbajosa, P. R. and Vila, J. Inappropriate use of antibiotics in hospitals: the complex relationship between antibiotic use and antimicrobial resistance. Enfermedades infecciosas y microbiologia clinica, 2013; 31: 3-11.

12. Methods for Dilution Antimicrobial Susceptibility Tests for Bacteria That Grow Aerobically; Approved Standard-Ninth Edition. CLSI document M07-A9. Wayne, PA: Clinical and Laboratory Standards Institute; 2012.

13. d'Avigdor, E., Wohlmuth, H., Asfaw, Z. and Awas, T. The current status of knowledge of herbal medicine and medicinal plants in Fiche, Ethiopia. Journal of ethnobiology and ethnomedicine, 2014; 10(1): 38.

14. Devi, P. N., Kaleeswari, S. and Poonkothai, M. Antimicrobial activity and phytochemical analysis of fruit extracts of Terminalia bellerica. International Journal of Pharmaceutica/Sciences, 2014; 6(5): 639-642.

15. Enyew, A., Asfaw, Z., Kelbessa, E. and Nagappan, R. Ethnobotanical study of traditional medicinal plants in and around Fiche District, Central Ethiopia. Current Research Journal of Biological Sciences, 2014; 6(4): 154-167.

16. Gebeyehu, G., Asfaw, Z., Enyew, A. and Raja, N. Ethnobotanical study of traditional medicinal plants and their conservation status in Mecha Woreda, West Gojjam of Ethiopia. Int $J$ pharm \& H care Res, 2014; 2:137-54.

17. Giday, M., Asfaw, Z. and Woldu, Z. Medicinal plants of the Meinit ethnic group of Ethiopia: an ethnobotanical study. Journal of Ethnopharmacology, 2009; 124(3): 513-521.

18. Giday, M., Teklehaymanot, T., Animut, A. and Mekonnen, Y. Medicinal plants of the Shinasha, Agewawi and Amhara peoples in northwest Ethiopia. Journal of Ethnopharmacology, 2007; 110(3): 516525.

19. Joy, V., Peter, M. and YesuRaj, J. Ramesh. Medicinal values of avaram (Cassia auriculata Linn.): a review. Int J Curr Pharm Res, 2012; 4(2): 1-3.

20. Kadi, H., Moussaoui, A., Benmehdi, H., Lazouni, H. A. and Benayahia, A. Antibacterial activity of ethanolic and aqueous extracts of Punica granatum L. bark. Journal of Applied Pharmaceutical Science, 2011; 1(10): 18.

21. Kidane, B., van Andel, T., van der Maesen, L. J. G. and Asfaw, Z. Use and management of traditional medicinal plants by Maale and Ari ethnic communities in southern Ethiopia. Journal of ethnobiology and ethnomedicine, 2014; 10(1): 46.

22. Koohsari, H., Ghaemi, E. A., Sheshpoli, M. S., Jahedi, M. and Zahiri, M. The investigation of antibacterial activity of selected native plants from North of Iran. Journal of medicine and life, 2015; 8(Spec Iss 2): 38. 
23. Kumar, S. G., Adithan, C., Harish, B. N., Sujatha, S., Roy, G. and Malini, A. Antimicrobial resistance in India: A review. Journal of natural science, biology and medicine, 2013; 4(2): 286.

24. Megersa, M., Asfaw, Z., Kelbessa, E., Beyene, A. and Woldeab, B. An ethnobotanical study of medicinal plants in Wayu Tuka district, east Welega zone of oromia regional state, West Ethiopia. Journal of ethnobiology and ethnomedicine, 2013; 9(1), 68.

25. Mesfin, K., Tekle, G. and Tesfay, T. Ethnobotanical study of traditional medicinal plants used by indigenous people of Gemad District, Northern Ethiopia. Journal of Medicinal Plants Studies, 2013; $1(4): 32-7$.

26. Molla, Y., Nedi, T., Tadesse, G., Alemayehu, H. and Shibeshi, W. Evaluation of the in vitro antibacterial activity of the solvent fractions of the leaves of Rhamnus prinoides L'Herit (Rhamnaceae) against pathogenic bacteria. BMC complementary and alternative medicine, 2016; 16(1): 287.

27. Moorthy, K., Srinivasan, K., Subramanian, C., Mohanasundari, C. and Palaniswamy, M. Phytochemical screening and antibacterial evaluation of stem bark of Mallotus philippinensis Tomentosus. African Journal of Biotechnology, 2007; 6(13):1521-1523.

28. Murthy, K. C., Vanitha, A., Rajesha, J., Swamy, M. M., Sowmya, P. R. and Ravishankar, G. A. In vivo antioxidant activity of carotenoids from Dunaliella salina-a green microalga. Life Sciences, 2005; 76(12): 1381-1390.

29. Murugan, T., Wins, J. A., \& Murugan, M. Antimicrobial activity and phytochemical constituents of leaf extracts of Cassia auriculata. Indian journal of pharmaceutical sciences, 2013; 75(1): 122.

30. Muthee, J. K., Gakuya, D. W., Mbaria, J. M., Kareru, P. G., Mulei, C. M. and Njonge, F. K. Ethnobotanical study of anthelmintic and other medicinal plants traditionally used in Loitoktok district of Kenya. Journal of Ethnopharmacology, 2011; 135(1): 15-21.

31. NCCLS (National Committee for Clinical Laboratory Standards). Methods Antimicrobial Susceptibility Tests for Bacteria that Grow Aerobically, 3rd Standard NCCLS document M100 S12. NC-275 CLS: Wayne, PA, USA, 2002.

32. Njoroge, G. N. and Bussmann, R. W. Traditional management of ear, nose and throat (ENT) diseases in Central Kenya. Journal of Ethnobiology and Ethnomedicine, 2006; 2(1): 54.

33. Obeidat, M. Antimicrobial activity of some medicinal plants against multidrug resistant skin pathogens. Journal of Medicinal Plants Research, 2011; 5(16): 3856-3860.

34. Palmer, A. C. and Kishony, R. Understanding, predicting and manipulating the genotypic evolution of antibiotic resistance. Nature Reviews Genetics, 2013; 14(4): 243.

35. Ramesh, N., Viswanathan, M., Saraswathy, A., Balakrishna, K., Brindha, P. and Lakshmanaperumalsami, P. Phytochemical and Antimicrobial Studies of Begonia malabarica, Ethnopharmacol. 2002; 79: 29-132.

36. Salama, H. M., \& Marraiki, N. Antimicrobial activity and phytochemical analyses of Polygonum aviculare L. (Polygonaceae), naturally growing in Egypt. Saudi journal of biological sciences, 2010; 17(1): 57-63. 
37. Sindhu, C., Beena Jose. Investigation of Antioxidant and Antibacterial Properties of Leaf, Root, Fruit and Stem Extracts of Trichopus zeylanicus from South India. International Journal of Pharmacognosy and Phytochemical Research, 2017; 9(1):135-140

38. Siyum, D. and Woyessa, D. Assessment of bacteriological quality and traditional treatment methods of water-borne diseases among well water users in Jimma Town, South West Ethiopia. Journal of Agricultural and Biological Science, 2013; 8: 477-86.

39. Sukhdev, S. H., Suman, P. S. K., Gennaro, L. and Dev, D. R. Extraction technologies for medicinal and aromatic plants. International Centre for Science and High Technology Trieste,

40. Summoro, T. S., Gidebo, K. D., Kanche, Z. Z. and Woticha, E. W. Evaluation of trends of drugprescribing patterns based on WHO prescribing indicators at outpatient departments of four hospitals in southern Ethiopia. Drug design, development and therapy, 2015; 9: 4551-4557.

41. Tadeg, H., Mohammed, E., Asres, K. and Gebre-Mariam, T. Antimicrobial activities of some selected traditional Ethiopian medicinal plants used in the treatment of skin disorders. Journal of ethnopharmacology, 2005; 100(1-2): 168-175.

42. Teklehaymanot, T. and Giday, M. Ethnobotanical study of medicinal plants used by people in Zegie Peninsula, Northwestern Ethiopia. Journal of ethnobiology and Ethnomedicine,2007; 3(1): 12.

43. Vandeputte, P., Ferrari, S. and Coste, A. T. Antifungal resistance and new strategies to control fungal infections. International journal of microbiology, 2011.

44. World Health Organization. Epidemiology and management of common skin diseases in developing countries Geneva. World Health Organization, 2005.

45. Yineger, H., Kelbessa, E., Bekele, T. and Lulekal, E. Plants used in traditional management of human ailments at Bale Mountains National Park, Southeastern Ethiopia. Journal of Medicinal Plants Research, 2013; 2(6): 132-153

46. Burt, S. Essential oils: their antibacterial properties and potential applications in foods-a review. International journal of food microbiology, 2004; 94(3): 223-253

47. Cantón, R., Horcajada, J. P., Oliver, A., Garbajosa, P. R. and Vila, J. Inappropriate use of antibiotics in hospitals: the complex relationship between antibiotic use and antimicrobial resistance. Enfermedades infecciosas y microbiologia clinica, 2013; 31: 3-11.

48. Lopez, P., Sanchez, C., Batlle, R. and Nerin, C. Solid-and vapor-phase antimicrobial activities of six essential oils: susceptibility of selected foodborne bacterial and fungal strains. Journal of agricultural and food chemistry, 2005; 53(17): 6939-6946.

49. Kaur, M., Singh, G. and Mohan, C. Barringtonia acutangula: A Traditional Medicinal Plant. J. Pharm. Sci. Rev. Res, 2013; 33: 168-171

50. Campbell M, Zhao W, Fathi R, Mihreteab M, Gilbert ES. Rhamnus prinoides (gesho): A source of diverse anti-biofilm activity. Journal of ethnopharmacology. 2019;15;241:111955. 